\title{
POLITICS IN THE TURKISH REPUBLIC OF NORTHERN CYPRUS
}

\author{
C.H. DODD
}

Neither Turkey nor the Turkish Republic of Northern Cyprus (TRNC) recognises the legitimacy of the Republic of Cyprus, and there is absolutely no doubt in either country about the legitimacy of the Turkish Republic of Northern Cyprus. This is a point worth while making at the beginning of any account of contemporary TRNC politics because in the TRNC a deep sense of moral indignation lies behind attitudes to the Cyprus issue and colours local politics-in which the Cyprus issue currently looms large.

The Turkish Cypriots maintain that by means of the notorious Akritas Plan (never denied) the Greek Cypriots made a deliberate and violent attempt to force them to accept minority status instead of the community status accorded them in the 1960 Constitution, and that this was intended to be a prelude to enosis. Despite the extreme violence to which they had been subjected, the Turkish Cyriot deputies made a request in 1965 (conveyed by UNFYCIP) to take their seats in the House of Representatives. This was refused unless they accepted serious limitations to their powers. ${ }^{1}$ This denies the Greek Cypriot contention that "since 1963 the Government continues to function without the Turkish members, who wilfully abstain from their duties..."2 The Turkish Cypriots maintain that their exclusion from the

\footnotetext{
${ }^{1}$ See Zaim M. Necatigil, The Cyprus Questlon and the Turklsh Position In International Law, 2nd ed., Oxford, 1993, p. 50, where UN evidence is quoted in support.

${ }^{2}$ Loukis G. Loucaides, "Observations on the Legal Position of the Cyprus Government since 1963 as a Matter of Municipal and International Law and of the So-called Turkish Republic of Northern Cyprus" (Paper provided to the author by the Cyprus High Commission, London). No date.
} 
major institutions of government, continuing Greek Cypriot violence, and the blockading of the enclaves to which they had to flee left them with no option but to govern themselves in the enclaves. ${ }^{3}$ They contend that by their actions the Greek Cypriots drastically altered the social and economic balance between the two communities-by reference to which the 1960 Constitution had been designed-and created fear and distrust in the Turkish Cypriot community. As the Greek Cypriots believed the constitution was 'unworkable', the proper way forward was, they believe, for them to insist on negotiations with the Guarantor Powers and the Turkish Community until constitutional changes could be agreed. Instead, to take matters into their own hands, to claim to rule by the 'doctrine of necessity' 4 and, further, to claim that the 1960 Constitution is still in force-all this to the Turkish Cypriots, in the circumstances above, stretches credulity beyond imaginable limits.

They also point out that the UN has been instumental since 1974 in promoting agreement by both sides to, not only a bi-communal, but also to a bi-zonal federal state, and that under the auspices of the UN both sides have been discussing, inter alia, the form of constitution appropriate for such a new state. Clearly, neither side seriously believes it is possible just to put the clock back, and suggestions to do so only harden attitudes in Turkish Cypriot politics.

\section{Political and Constitutional Developments: 1975-1990}

\section{Opportunities for the Left:}

In 1975 the Turkish Cypriots established the Federated State of Northern Cyprus claiming that this would ease movement towards a federated state in Cyprus. Although generally decried by the Greek Cypriot side, this consolidation of government in the North did not greatly perturb the outside Powers. Shortly after its establishment, in fact, negotiations between Makarios and Denktaş went well resulting in the important set of principles agreed in 1977. It seems to have been generally accepted in the North at this time that a federation would come about. In the meantime, the new state was deeply involved in domestic disputes, made difficult by numbers of refugees, and by a difficult, if slowly improving, economic situation. Moreover, these difficulties occurred at a time when the left was strong in Turkey, and was not without its effect in Northern Cyprus.

\footnotetext{
${ }^{3}$ The UN Secretary-General's Report to the Security Council, S/6268, 11.3.1995, stated that the writ of the Greek Cypriot Government had not run in these areas since December, 1963. (As reported by Necatigil, The Cyprus Question, p. 60). The Greek Cypriot view is that selfgovernment was prompted by the desire for partition.

${ }^{4}$ For a refutation of the 'doctrine of necessity' see Necatigil, p. $51 \mathrm{ff}$.
} 
In fact, the influence of the left so developed by 1981 that its strength in the elected National Assembly was almost enough to topple the rightwing government of the National Unity Party, which Denktaş had set up a few years earlier, but no longer led as President of the new state. The issues at the time were overwhelmingly domestic, relating very little to the Cyprus problem, but if the left had come to (and remained in) power, Turkish Cypriot attitudes to the Cyprus problem, as it later intensified, might have been very different. The narrow victory of the right was important in this regard. 5

After 1981 the power of the left-wing parties represented by the new Communal Liberation Party, and the older, and generally more left, Republican Turkish Party began to decline. Influential in this were some members of the Communal Liberation Party who became disillusioned with the extreme left, and increasingly suspicious of Greek Cypriot aims once Papandreou came to power in Greece in 1981. One former, and powerful, critic of Denktas was Fuat Veziroğlu. He, and other members of the left now supported moves which led to the Declaration of Independence in 1983, and the establishment of the Turkish Republic of Northern Cyprus. Veziroğlu largely master-minded the strategy by which this was achieved. 6

The Declaration of Independence won a unanimous vote in the Assembly though the left-wing parties claimed that they had been intimidated by being told that if they did not vote for the Republic, they would, logically, exclude themselves from it after it had been voted for by the majority. They also realised that a referendum on the Declaration of Independence, which was the original plan, would almost certainly have been approved. They could not afford to be out of step with public opinion, which widely supported Denktaş in this issue of independence. (In the presidential election of 1985 , Denktaş obtained $70.2 \%$ of the vote, as against $51.7 \%$ in 1981).

\section{The Ascendancy of the Right:}

Whilst Denktas did well in the 1985 presidential election, the same cannot be said for the National Unity Party in the general election-showing that Denktaş must have taken votes from supporters of left-wing parties. The National Unity Party obtained just a few votes less than the combined vote of the two left-wing parties, and won only two more seats in the Assembly. Wishing not to rely on the four members elected by supporters of the

\footnotetext{
${ }^{5}$ A detailed treatment of this period is in C.H. Dodd, ed., The Political, Soclal and Economic Development of Northern Cyprus, Huntingdon, 1993, p. 121 ff.

${ }^{6}$ Ibld., p. 124 ff.
} 
'immigrants' party, the new Birth Party, the NUP entered into uneasy coalition with the now less extreme Communal Liberation Party. The coalition was full of troubles, some personal, but mostly ideological, and finally broke down when, under the influence of Özal's government in Turkey, the TRNC's economical policies were heftily shifted in a new 'market' direction. The Communal Liberation Party decided it could not continue to profess socialism and espouse Friedmanite economic doctrines at the same time. The National Unity Party then had to form a coalition with the New Birth Party, which was eager for office. Still unsure of itself, however, the National Unity Party passed an electoral law designed to weight the vote in its favour in the next general election, on the common enough ground that coalition governments were not in the national interest.

This was objected to by the opposition parties with the result that democracy, or, better, the lack of it, became the major political issue. President Denktas joined in the critique of the NUP, which was now led by the independent-minded Derviş Eroğlu. Then, the two left-wing parties, and surprisingly, the New Birth Party, decided to join forces for the 1990 elections. ${ }^{7}$ It was a gamble they lost, their Democratic Struggle Party never really getting a programme together. Fifty-five per cent of the vote went to the NUP, who thus obtained thirty-four out of the fifty seats. Claiming Turkish media interference in the election, the two major left-wing parties boycotted the Assemly. This was a problem for Denktas, as chief spokesman in foreign affairs, having to contend with accusations abroad that 'his' party had set up single party government. He had himself maintained his popularity in 1990 by obtaining $66.7 \%$ of the vote in the presidential election. It is worth a wry note that without changing the electoral law the NUP would almost certainly have won a majority of seats in the Assembly.

\section{Relations between Government and President:}

The dispute over the electoral system was one factor in the deteriorating relations of President Denktaş with Prime Minister Eroğlu. Another was the government's continuing inaction in promoting legislation for an ombudsman, which Denktaş badly wanted-possibly as a means of putting limits on patronage and clientilism, which are particularly prevalent in small societies, or simply in order to exercise more control over administration. A third, and increasingly important, source of friction was the clear inclination of Eroglu to take a harder line on the Cyprus issue than Denktaş believed was possible or wise. On a governmental proposal to amend the electoral law in a way which still favored the party likely to get the largest vote (i.e. the NUP), neither a personal appearance by the President

\footnotetext{
${ }^{7}$ The New Birth Party, the immigrants' party, was not, however, successful in
} attracting most of their votes. 
before the Council of Ministers, nor the President's request for a referendum on the issue had any effect on the government. In the upshot it was only the mediation of Erdal Inonü from Turkey which produced a compromise.

In the meantime, opposition to Eroğlu's leadership began to appear in the National Unity Party on this issue of the electoral law. It was led by Hakkı Atun, supported by, among others, the President's son, Serdar Denktaş. This led in July 1992 to the emergence of a splinter party, the Democratic Party.

By 1993 relations between Denktaş and Eroğlu had seriously deteriorated, and it was open knowledge that the President supported the Democratic Party. The President complained that he was not supported in his international role by Eroglu, even though he had the confidence of Ankara. Matters came to a head in July 1993 when Denktaş resigned as negotiator in the UN discussions. He had just returned from New York where he had been under great pressure to accept the Confidence Building Measures-and from Ankara where he had received from the Grand National Assembly full support for the doubts he was expressing about the CBM's, and a standing ovation. His resignation left the UN the prospect of negotiation with the avowedly less amenable Eroğlu, who had declared that not a scrap of territory should be given back to the Greek Cypriots. It is doubtful if he was much believed, or even much known, in an outside world suffering from 'Denktaş phobia'. All now had to wait for the general election for which the opposition parties and Denktaş were pressing, but in favour of which the major influence seems to have been that of the Turkish Government.

\section{The December 1993 General Election:}

The political parties entered into the elections with programmes embracing a number of fields, but which gave first, though not exclusive, place to the Cyprus issue. The Communal Liberation Party stressed the legitimacy of the 1974 intervention and a federal solution which recognised the equality of the Turkish Cypriots. Whilst it stressed the immediate need for federation, it had to be carefully worked out, and not under pressure. In the result the Turkish Cypriots must be allowed to live together in their own community, and with the continuation of the Turkish guarantee. By political equality the party meant the separate rights of the Turkish Cypriot and Greek Cypriot peoples to self-determination. ${ }^{8}$ And, it was claimed, not enough effort had been expended by either the TRNC or Turkey to have the new republic internationally recognised.

\footnotetext{
${ }^{8}$ Toplumcu Kurtuluş Partisi, 1993 Seçim Bildirgesi (1993 Election Manifesto).
} 
The Republican Turkish Party's programme has moved more than that of the Communal Liberation Party, not being anything like as leftist as it was. A striking symbol of this is the change of the party's distinguishing colour to green-not for Islam, but for 'dialogue, peace, brotherhood' and, not least, the environment. The party, does not even demur now about 'the Turkish guarantee.'

A major issue in the election was, udoubtedly, the policy and personality clash between the two right-wing parties. The Democratic Party made a lot of Eroglu's refusal to give back a scrap of territory and his dislike of any federation with the Greek Cypriots. At the same time, perhaps realising the attractiveness amongst the electorate of a firm line on the Cyprus issue, the Democratic Party declared that the NUP was simply putting on a show and was essentially unprincipled. In its campaign the National Unity Party proclaimed that any move that sought to destroy, in effect, the existence of the TRNC, or to change the existing territorial arrangements, was destined to failure. Without the recognition of the TRNC a fundamental settlement was impossible. No proposals could be accepted which would turn our people into refugees again, it was declared, with Greek Cypriot claims to the Güzelyurt/Morphou area chiefly in mind it seems. The party was also against 'mini-packet' deals, like giving back Maraş/Varosha, in place of international recognition. Nevertheless, the party declared itself in favour of an agreement with the Greek Cypriots which did not call for concessions on rights so far gained, or for territory. The margin for negotiation seems slight.

\section{Election Results:}

The results of the general election were eagerly awaited, but did not much surprise the pollsters. They were as follows:

$\begin{array}{lrcr}\text { National Unity Party } & 29.85 \% & \text { of vote } & 17 \text { seats } \\ \text { Democratic Party } & 29.19 \% & \text { do. } & 15 \text { do. } \\ \text { Republican Turkish Party } & 24.16 \% & \text { do. } & 13 \text { do. } \\ \text { Communal Liberation Party } & 13.27 \% & \text { do. } & 5 \text { do. }\end{array}$

Three small parties did not gain seats.

The Communal Liberation Party showed that it had not recovered strength since its poor result in 1985 , when it obtained $15.8 \%$ of the vote. The Republican Turkish Party's vote increased from $21.4 \%$ in 1985 to 24.16 $\%$, probably reflecting its more moderate stance. The joint left-wing vote was practically the same as in 1985 , at 37.43 per cent. ${ }^{9}$

\footnotetext{
${ }^{9}$ A suggestion by Kevin Watkins, Report (Friends of Cyprus, London) no.
} 36 (Spring, 1994), p. 6, that there was "a marked significant increase in 
The National Unity Party and the Democratic Party together received a rather greater proportion of the vote than the NUP did on its own in 1990, but no doubt the New Birth Party vote went to the Democratic Party after its earlier amalgamation with it. Clearly, the strength of the right seen in 1990 has been more than sustained, despite the split.

It is sometimes claimed that the immigrants from Turkey vote for the National Unity Party and are instrumental in keeping Denktaş in power. These issues can be nicely confused. Even the European Commission, in its Opinion on the application for membership of the EU by Cyprus, which it issued in 1993, stated, "Mr. Denktash...holds a large majority in Parliament owing mainly to the Turkish settlers' vote." 10 Leaving aside the ignorance of the TRNC's political system which this remark reveals, we might assume that what is meant is that the National Unity Party obtains its majority from the immigrants' votes.

However, research into voting in twenty-four immigrant villages in the 1990 general election shows

(i) that the majority of votes went to the Democratic Struggle Party (51.39\%), not to the NUP (47.56 \%), and

(ii) that their support for the NUP was seven per cent points less than support overall in the TRNC for the NUP.

These results would be affected to some extent by the fact that the Democratic Struggle Party contained the small immigrants' party, the New Birth Party, but this would not be by more than a few percentage points.

In the presidential election held in the same year most of the immigrants in these villages voted for Denktaş, but only $59.38 \%$ of them, as compared with $66.72 \%$ who voted for him in the country as a whole. Proportionately more voted for the Communal Liberation Party candidates in these villages than in the country generally. Clearly, this research shows that immigrants divided their votes, and even then in favour neither of the NUP nor Denktaş.

It has been asserted of the December 1993 general election:

popular support for Opposition parties" is not correct. He compares voting in a presidential election with voting in a general election, but the left-wing vote is always far lower in presidential than in general elections.

10 "Commission Opinion on the Application by the Republic of Cyprus for Membership", Commission of the European Communities, Com (93) 313 final, (Brussels, 30.6.1993), p. 9. 
"With thousands of illegal Turkish settlers registered to vote, probably accounting for around $20 \%$ of the electorate, there was never a serious prospect of them [the RTP and the CLP] gaining an outright majority... It appears likely that the bulk of the settler vote went to the Democratic Party..."11

However, voting patterns in the same villages studied in 1990 are as follows (in percentages): 12

$\begin{array}{llllr} & \text { NUP } & \text { DP } & \text { RTP } & \text { CLP } \\ \text { Immigrants } & 29.62 & 39.07 & 19.00 & 8.23 \\ \text { TRNC overall } & 29.85 & 29.19 & 24.16 & 13.27\end{array}$

It seems that the 10 per cent above average vote for the Democratic party is accounted for by the New Birth Party's joining the Democratic Party before the election. It is unlikely that the immigrants who voted DP did so because Denktaş was popularly associated with that party-they voted differentially against him in the 1990 presidential election. Assuming that of all the immigrants only some 27 per cent voted for the left, and that the immigrants constitute some 20 per cent of the electorate, the overall vote for the left-wing parties could not have been more than a few percentage points higher. The immigrants did not stop the left from gaining power.

How far the December 1993 voting patterns are being maintained is broadly indicated in the voting for municipality councils in June 1994. In these elections the results were (in percentages of votes):

$\begin{array}{lr}\text { National Unity Party } & 25.8 \\ \text { Democratic Party } & 22.5 \\ \text { Turkish Republican Party } & 30.3 \\ \text { Communal Liberation Party } & 15.2 \\ \text { Others } & 6.2\end{array}$

The combined right only did some $2 \%$ less well than in the 1986 local elections. The 1990 local elections were boycotted by the RTP and CLP.

\footnotetext{
${ }^{11}$ Report, p. 6

12 This valuable research is by Dr. Jonathan Warner of the Eastern Mediterranean University. "Importing Voters: Does it Work?", New Cyprus, Sep.-Oct., 1990, 34-5. The work on the 1993 general election has been privately supplied to the author.
} 
From the distribution of votes in the general and local elections it is evident that the TRNC is not a one-party state. It is also evident that Denktaş cannot decide everything, as some outside observers assume. The opposition to Denktaş is now less strident than it used to be, but clearly there is also now a change in that opposition coming more seriously from the right than from the left, now that the left has moved to more moderate policies and attitudes.

\section{Coalition Government:}

For the present, it is significant that the left-wing parties' approach to the Cyprus problem shows more caution in dealing with the South. It is this change of attitude that has allowed the Republican Turkish Party to form a coalition with the Democratic Party.

The protocol establishing the coalition government makes this clear. It was agreed that any Cyprus settlement must be based on (1) the equal political status of the two communities, (2) joint sovereignty [not the single sovereignty of the Republic of Cyprus], (3) a bi-zonal, bi-communal federation, and (4) a continued effective guarantee from Turkey.

It is especially tempting, it is fair to assume, for a party never previously in office, to join in government. For the RTP public office provides benefits, opportunities, and prestige which will enable it to gather future support, and helps push its left-wing rival further into the shade. It is significant that the party once so hostile to Denktaş, has now joined in a coalition which, through the Democratic Party, represents a good portion of his views.

The new accord was severely tested in August 1994. Responding to the virtual ban on Turkish Cypriot exports to the European Union imposed by the ruling of the European Court of Justice in July 1944, "the negative and intransigent attitude of the Greek Cypriot administration" in recent negotiations, and its collaboration with Greece in re-armament and in pressing for unilateral membership of the European Union, the Assembly debated some important matters of general policy, matters on which the President had already expressed himself forcibly.

The Assembly debate (28 August) lasted for fourteen and-a-half hours. The break-up of the coalition seemed imminent at some stages. The absolute abandonment of a federation with the Greek Cypriots was impossible for the left to accept. The final version of the Resolution passed by the Assembly was not as severe as had been expected. In the voting on the Resolution there were 30 in favour and 16 against, two members from both the left and right being absent. The demise of the coalition government would seem to be 
inevitable. The Republican Turkish Party voted solidly against the Resolution, but did not resign from the government!

The Assembly Resolution stated, first, that "no good would come out of the negotiations on the Confidence Building Measures" whilst the decision of the European Court of Justice remained in force, and "the Greek Cypriot of the European Union". Secondly, the 'separate' sovereignty of the Turkish Republic of Northern Cyprus was insisted upon. Thirdly, any new negotiations would have "to take into account the political equality and sovereignty rights of the Turkish Cypriots". Fourthly, it was an "inevitable necessity" for the TRNC and Turkey to take measures "commensurate with those military and defence measures taken by Greece and Greek Cypriots, by concluding agreements with Turkey on foreign affairs, defence and security". The Assembly also underlined "the need for the Government to begin as soon as possible initiatives for lifting all restrictive measures between TRNC and Turkey in the economic field and thus completing the economic integration between the two countries". Finally, the Assembly repealed previous resolutions in 1984 and 1985 which envisaged "federation as the sole form of settlement in Cyprus". ${ }^{13}$

At least something was saved by the opposition from the left: federation was not entirely ruled out. This did not stop the RTP wing of the government; nevertheless, it was a tactical victory for the Democratic Party wing of the government-and partially for the President, who wanted this legislation. It is akin to the acquiscence of the left in 1983 to the Declaration of Independence. Now, as then, hostile external pressures provided an opportunity for forcing the opposition either to stick to its principles and policies, and face public obloquy for disloyalty to the country, or to bow to public opinion and compromise its general stance. Those who seek to exert abnormal pressures on the Turkish Cypriots may not sufficiently realise how they strengthen their opponents at the expense of their friends.

Shortly after this crisis the resignation of the Assembly Chairman, Ayhan Halit Acarken, from the Democratic Party left the two coalition partners in balance, with thirteen seats each in the Assembly. The increased importance of the RTP coalition partner suggested to many that the most stable and representative coalition would be one of the Democratic and National Unity parties, but the fact that Eroğlu was leader of the latter made that very difficult. Moreover, the internal coherence of the NUP, and the strength of its leader seemed to be underlined when he was re-elected leader with a sixty-eight per cent majority. However, support was not completely solid. In November 1994 Enver Emin, who had challenged Eroğlu for the

13"Resolution by the Parliament of the Turkish Republic of Northern Cyprus on 28 August, 1994" (English), Lefkoşa: President's Office, 1994. 
leadership, set up the National Birth Party (Ulusal Doğuş Partisi), though drawing just one deputy from the NUP to his side. There was a further weakening, however, when Salih Coşar, a figure in the party, moved to the Democratic Party, where he eventually became Minister of Finance.

President Denktaş had for some time declared that he would not stand again in the presidential elections due in April 1995. As he has often pointed out, the president has little formal power in the Constitution. President Denktaş, through his experience and charisma, had been able to wield practically complete power in international affairs, especially the management of the Cyprus dispute, though he had been subject to serious challenge in 1993 by the government led by Eroglu. A new incumbent could not expect to be much more than a figurehead, and the position would be difficult for Denktaş if Eroğlu were to be in power.

There was a good deal of popular concern, however, that in the difficult internal political circumstances obtaining, not to mention the problems being created by the South's application to join the EU, Denktas was not going to stand again. In the end, therefore, in January 1995 Denktas responded to popular pressure and decided to stand, whilst making it clear that he wished the president had more power. It was generally agreed that there was no one person in politics with the experience and stature to replace him.

That Denktaş decided to stand again became even more important when at the end of February the coalition government collapsed. It was not a happy union. In January, a dispute had broken out over the settling of the minimum national wage. The Democratic Party at first rejected the figure proposed by the commission authorised to recommed the amount. Business circles behind the Democratic Party claimed that the figure recommended would create unemployment. The crisis became serious, especially as the President showed sympathy for the commission's proposed wage (c. \$ 235 per month) The Democratic Party gave way.

Then, in the middle of February, legislation to give 'clean' deeds to some 17.000 families for property allocated to them from former Greek Cypriot property was rejected by the Republican Turkish Party's wing of the government. Those affected by the proposals were refugees from the South, Turkish immigrants, resistance fighters before 1974, those who had fought against the Greek Cypriots in 1974 and the families of those who had died in the struggle. The new title deeds would give them the right to sell, transfer and mortgage their properties free from government restriction. There was nothing basically new about the legislation, however. To some eighty-five per cent of holders of former Cypriot Greek property 'clean' deeds had alrready been distributed. The RTP coalition partner objected that to pass such legislation just before the presidential elections was improper. (The Democratic Party would undoubtedly get the greatest credit for a popular 
move, and that party would be supporting Denktas). The RTP wanted to secure the agreement of all parties to the legislation or to leave it until after the presidential elections. The RTP thought too that those who rented property from the state should also receive deeds of ownership. In the upshot the RTP wing of the coalition would not agree that the law be passed. Critics believed that one reason for rejection of the proposed legislation by the RTP was that it would push the party politically further to the nationalist right than it wanted to be seen to go. Hence, its desire for all parties to agree to the legislation. As the party always most inclined to come to agreement with the South, it would be prejudicing its position by supporting a move that would complete the transfer to private ownership Greek Cypriot property abandoned in 1974. Other, more cynical, critics have suggested that the dispute was not about the property legislation at all, but that the Democratic Party was not prepared to countenance some special provision for public employees who had been appointed at the behest of the Republican Turkish Party coalition partner.

As a result of this disagreement, ostensibly over the new legislation, the coalition government fell at the end of February. It provided an opportunity for President Denktaş to press again the case for the greater stability of presidential government, but unless it proves absolutely impossible to form a government, when there would anyway have to be a new general election, there is little prospect of development in that direction. To ask two-thirds of the deputies (the proportion required) virtually to vote themselves out of the chance of office seems out of the question. Only a major crisis could bring it about.

\section{Conclusions:}

From this study some conclusions emerge. In the first place, the strength of the right in Turkish Cypriot politics has not declined, nor has that of the left advanced. Small parties have virtually disappeared, with changes in the electoral laws. The scene is one of considerable stability overall, though the division of the right makes it difficult, for personality rather than for policy reasons, to create the stable government of the moderate right that the electors clearly prefer.

Secondly, the policy orientation of left and right, both in internal and international affairs, has come closer, especially on the Cyprus issue. But a division has emerged on the right with the development of greater inflexibility on the Cyprus issue in the National Unity Party now with Eroğlu's leadership confirmed.

Thirdly, the immigrants (estimated to be some 40.000 , in the absence of reliable statistics) do not vote for the right-wing parties exclusively, but 
split their votes, and are rather than less than averagely enthusiastic about Denktaş.

Fourthly, a more general point, the more external pressure is exerted on the TRNC, the more intransigent the Turkish Cypriots seem to become, and the more determined to stress their right of self-determination and their sovereignty. They are helped in this by the fact that the Cyprus issue can easily arouse popular sympathy and support in Turkey which no politician can afford to ignore. Moreover, given the periodic escalation of alarm in Greece and Turkey over Aegean problems, the Turkish military cannot be expected to be indifferent to any military alliance between Cyprus and Greece, or the provision of military facilities to Greece in Cyprus.

Finally, underlying Turkish Cypriot politics is the injustice Turkish Cypriots feel at the treatment of the TRNC by the United Nations and the European Union and the apparent incapacity of these bodies to see the Cyprus problem in any but Greek Cypriot terms. In particular, Turkish Cypriots feel that support for Greek Cypriot embargoes, without any questioning of the legitimacy of the Republic of Cyprus, has quite unjustifiably crippled their economy. It has had the effect of driving them closer to Turkey. Not all Turkish Cypriots want this to happen, but they prefer it to not being treated equally with the Greek Cyriots. Less than half think that a federation with the Greek Cypriots will be successful. ${ }^{14}$

To suggest what may happen in the future is always hazardous. It is wiser to indulge that capacity for hindsight we all amply possess. All appears to be in flux in Turkish Cypriot politics. However, polls show that the chances of Denktaş's success in April against his rivals. Eroğlu and Özgür are high. ${ }^{15}$ The major difficulties lie in party politics. Only with the settlement of difficult personal rivalries would stability seem possible.

\footnotetext{
${ }^{14}$ As reported in a public opinion survey conduced by the Turkish survey organisation ONAR, reported in Kıbris, 2 and 3 February. 15 Ibid.
} 